\title{
Franci AvSEC* \\ The preemption right on agricultural land in Slovenia: past developments and future challenges
}

\author{
Abstract
}

\begin{abstract}
The paper outlines statutory preemption rights relating to agricultural land in Slovenia, in particular the priority right to purchase agricultural land which is regulated by the Agricultural Land Act. This preemption right has a general scope and a long tradition (of nearly 60 years). In the previous legal system, based on the social ownership as basic ownership form, the statutory preemption right on agricultural land was first introduced for agricultural organisations and later also for private farmers (who were ranked after agricultural organisations). At first, the preemption right related only to privately owned agricultural land and had a limited impact for farmers due to agricultural land maximum. After the agricultural land maximum was abolished in the beginning of the 1990s and the statutory preemption right was extended to all agricultural land, the development has been characterised by endeavours to make the statutory preemption right more efficient in practice and consistent with the principle that restrictions the legislator imposes on the constitutionally guaranteed private property must be in public interest and proportional. A Draft Act launched for public consultation in spring 2019 foresaw several substantial changes of the statutory preemption right linking this right more closely to farm structure improvement and overall agricultural policy, but has not been further elaborated after the consultation was closed in May 2019.
\end{abstract}

Keywords: agricultural land, statutory preemption right, Slovenia.

\section{Introduction}

The premption right in the agricultural land law is an interesting legal institute in the Slovenian legal system for at least three reasons.

Firstly, the legislation in Slovenia has been shaping this right since the early 1960s. Numerous modifications, amendments and refinements faithfully mirror interpretative problems and legal gaps, changes of agricultural policy as well as of the whole legal and socioeconomic system. Some radical systemic changes did not abolish the statutory preemption right, but turned, although not in one step, the priority order of the statutory preemptors upside down. Therefore, the knowledge about past legislative amendments and important interventions of the Constitutional court contribute to a better understanding of the present regulation and its future challenges.

Secondly, the Agricultural Land Act is not the only piece of legislation regulating statutory preemption right that relates or may relate to agricultural land. Preemption

Franci Avsec: The preemption right on agricultural land in Slovenia: past developments and future challenges. Journal of Agricultural and Environmental Law ISSN 1788-6171, 2020 Vol. XV No. 28 pp. 9-36, https://doi.org/10.21029/JAEL.2020.28.9

* PhD, Associate Professor, Faculty of Economics and Informatics, University of Novo mesto, Slovenia, e-mail: favsec@gmail.com

https://doi.org/10.21029/JAEL.2020.28.9 
Franci Avsec

The preemption right on agricultural land in Slovenia: past developments and future challenges
Journal of Agricultural and

Environmental Law

$28 / 2020$

right on agricultural land is laid down in also in other acts dealing with agricultural land or, more generally, with real estate that is specially protected as natural or cultural heritage, riverine land etc. In such cases the question arises which statutory preemption right has precedence before others, in what priority order the statutory premptions rights are being exercised or whether the special provisions on preemption rights abrogate the general ones.

Thirdly, a statutory preemption right has a dual nature. According to the caselaw of the Slovenian Constitutional court, a statutory preemption right is a restriction of the constitutionally guaranteed private property ${ }^{1}$ and, on the other side, also a special property right which itself enjoys a constitutional protection of private property $^{2}$. Therefore, the exercise of the statutory preemption right may be connected with various problems in practice: an owner intending to alienate agricultural land may avoid the preemption right which restricts her freedom to choose a buyer, while a statutory preemptor may exercise her preemption right not in accordance with the purpose for which it was established by legislation.

Apart from the introdution, the paper consists of four sections. The second and the longest section briefly outlines the development of the statutory preemption right on agricultural land in Slovenia since the introduction of this right in 1962. The historical survey shows how past choices defined further development of statutory preemption right on agricultural land as a legal institute (the so called path dependency). The third section describes other preemption rights that are regulated outside the Agricultural Land Act, but relate or may relate also to agricultural land, analysing the relationship between preemption rights on the same agricultural land. The fourth section resumes main changes for the future regulation of the statutory preemption right proposed by the Draft Act on modifications and amendments of certain laws concerning agricultural land policy which was launched for public consultation in spring 2019.

The conclusion deals with factors which determine the practical impact of the statutory preemption right, including some issues dealt by theory and the court practice, including sham and fraudulent contracts.

\footnotetext{
1 "... the enacting of the preemption right is an encroachment upon the right to own and inherit property (Article 33 of the Constitution) - a violation of freedom of enjoyment of the same, which also includes the disposal with an apartment in legal transactions - and such an encroachment can only be in conformity with the Constitution to the extent that it is justified by the need to ensure economic, social and environmental functions of property (Article 67 of the Constitution), or insofar as this is unavoidable because of the protection of rights of other persons (in accordance with the principle of proportionality)." Decision no. U-I-119/94 para 6, Official Journal of the Republic of Slovenia no. 24/1996.

2 "The pre-emption right thus constitutes, under the general rules, an undertaking by the owner of the thing (seller) to inform the preemption beneficiary of the intended sale of the thing to a certain person and of the terms of that sale, and to offer him to buy it under the same conditions (...). According to the Constitutional Court, the said position of a pre-emptive beneficiary under a legal pre-emptive right is protected under the right to private property referred to in Article 33 of the Constitution." Decision no. Up-1581/18-22 para 14, Official Journal of the Republic of Slovenia no. 29/2019.
} 
Franci Avsec

The preemption right on agricultural land in Slovenia: past developments and future challenges
Journal of Agricultural and

Environmental Law

$28 / 2020$

\section{Past development}

\subsection{Geographical and historical background}

According to the last available data of the Slovenian Surveying and Mapping Authority, the total surface Slovenia $\left(20,273 \mathrm{~km}^{2}\right)$ is mostly covered by forests $(58 \%)$, while the agricultural land represents only $33 \%$ of the total surface. ${ }^{3}$ Nearly $90 \%$ of the territory lies 300 metres or more above the sea level, while plain areas account for less than $20 \%$ of the territory. ${ }^{4}$ The statistical data show high scarcity of agricultural land in Slovenia, compared with other countries. According to the last available data, the share of utilised agricultural area in the total surface of Slovenia was $23.5 \%$, in the EU-28 as a whole $40.0 \%$, while the arable land represented in Slovenia only $35.6 \%$ of the total utilised agricultural area, compared to $81.6 \%$ in the neighbouring Hungary and $59.8 \%$ in the EU-28 as a whole. ${ }^{5}$

Given a relatively high scarcity and great fragmentation of agricultural land in Slovenia, the preemption right relating to agricultural land has been an important tool of agricultural land policy with a long and very dinamic development since the early 1960s.

In that time, the agricultural land structure was marked with the prevailing private ownership of the land (in 1962, 88.3\% of agricultural land and $63.3 \%$ of forests in Slovenia were in private ownership), ${ }^{6}$ while the most part of productions means in non-agricultural sectors of the economy belonged to the so called social ownership as the prevalent ownership form in the legal and economic system.

The agricultural structure of the country had been substantially changed by a radical agrarian reform regulated by the Yugoslav Act on agrarian reform and colonisation $^{7}$ and the same-named Slovenian act, ${ }^{8}$ both adopted in 1945.

The agrarian reform was based on the principle that "The land belongs to those who cultivate it" 9 and provided for the maximum surface of agricultural land and

\footnotetext{
3 Statistika REN 2018, While collecting data about various land categories, the agricultural statistics distinguishes data referring to land cover from those relating to land use, the former being related to natural features and the latter to the socioeconomic role of the land. For additional information Eurostat 2012.

${ }^{4}$ Rural development programme of the Republic of Slovenia 2014-2020, 2015, 2.1.

${ }^{5}$ Kmetijski inštitut Slovenije, Slovensko kmetijstvo v številkah, Ljubljana 2018, 6. and Eurostat 2019.

6 Statistical Yearbook of Socialist Republic of Slovenia 1964, Ljubljana, 123. and own calculations.

7 Official Journal of the Democratic Federative Yugoslavia no. 64/1945, Official Journal of the Federative People's Republic of Yugoslavia no. 24/1946, 101/1947, 105/1948, 21/1956, 55/1957, Official Journal of the Socialist Federative Republic of Yugoslavia no. 10/1965.

${ }^{8}$ Official Journal of Slovenian National Liberation Council and of the People's Government of Slovenia no. 62/1945, Official Journal of the People's Republic of Slovenia no. 30/1946, 10/1948, 17/1958, 17/1959, 18/1961, Official Journal of Socialist Republic of Slovenia no. $22 / 1965$.

9 This principle was repeated by the Yugoslav Constitution from 1946, Official Journal of the Federative People's Republic of Yugoslavia no. 10/1946, Art. 19(1) and the Constitution of the
} 
forests that might be owned and used by individuals. The land maximum was determined for farmers on a higher level than for other individuals. Thus, members of a farmer holding were allowed to own and use, in principle, no more than 20-35 hectars (ha) of agricultural land and 10-25 ha of forests, while 45 hectares represented a maximum total surface of agricultural land and forests of a private farmer holding unless the competent minister exceptionally allowed a larger surface in areas with low soil fertility. ${ }^{10}$ A lower maximum was prescribed for non-farmers (3 ha of agricultural land or, in areas with no agricultural land, 5 ha forests per holding). ${ }^{11}$ After a strong political campaign for establishment of peasants' working cooperatives following example of the Soviet kolchoses had definitely failed, an additional land maximum was introduced for farmers in 1953 (10 ha of arable land in lowland and 20 ha of arable land in hilly and mountainous regions). ${ }^{12}$

The federal Land and Buildings Transactions Acts from 1954 provided that agricultural land in social ownership might not be alienated, unless otherwise provided by the law. ${ }^{13}$

As the private agriculture was marked by a great fragmentation of land and fast decrease of active population in agriculture, the agricultural policy in the early 1960s planned faster development of socially owned agricultural enterprises in order to achieve higher productivity growth and improvement of self-supply of the country. ${ }^{14}$ Among other measures to reach this goal, the premption right of agricultural organisations on privately owned agricultural land was introduced.

\subsection{The introduction of statutory preemption right for agricultural organisations in 1962}

The Yugoslav (federal) Basic Agricultural Land Exploitation Act from 1959 introduced, inter alia, the priority right of agricultural organisations (entreprises carrying out agricultural activities with socially owned agricultural land and other means of production) to take on lease agricultural land in private ownership (the so called 'citizens' ownership')..$^{15}$ The amendments of this Act from $1962^{16}$ granted agricultural organisations also the priority right to purchase privately owned agricultural land if it

People's Republic of Slovenia from 1947, Official Journal of the People's Republic of Slovenia no. 20/1947, Art. 18(1).

10 Act on agrarian reform and colonisation in Slovenia, Official Journal of the Slovenian People's Liberation Council and Official Journal of the Slovenian People's Liberation Council and People's Government of Slovenia no. 62/1945, Art. 12.

11 Ibid. Art. 11.

12 Act on agricultural land fund of common people's property and allocating land to agricultural organisations, Official Journal of the Federative People's Republic of Yugoslavia no. 22/1953.

${ }^{13}$ Conf. Zakon o prometu z zemljišči in stavbami, Official Journal of the Federative People's Republic of Yugoslavia no. 26/1954, Art. 1(1).

14 Prinčič 1999, 164.

15 Temeljni zakon o izkoriščanju kmetijskega zemljišča, Official Journal of the Federative People's Republic of Yugoslavia no. 43/1959, Art. 83.

16 Zakon o spremembah in dopolnitvah Zakona o izkoriščanju kmetijskega zemljišča, Official Journal of the Federative People's Republic of Yugoslavia no. 53/1962. 
was offered for sale. The procedural issues were dealt only by two provisions, namely that an owner who intended to sell agricultural land was obliged to announce the sale offer on the noticeboard of the local office or of the municipality and that the sale of agricultural land to an (individual) agricultural producer was allowed only if no agricultural organisation 'wanted' to purchase the land. The Act laid down no period for acception of the offer by agricultural organisations (amended Art. 83 of the Act), but explicitly provided that a an individual agricultural producer (a farmer) or other citizen as a buyer might apply to be registered as a new owner of the land concerned in the land registry only if she submitted a certificate issued by the municipal authority confirming that the provisions on preemption right had been complied with (Art. 93).

\subsection{Preemption right for farmers introduced by the Slovenian legislation (1973)}

In the beginning of the 1970s, the legislative competences relating to agricultural land were to a great extent transferred from the federation to republics and autonomous provinces. In that time it became obvious that privately-owned agriculture with $85.8 \%$ share in agricultural land and $61.5 \%$ share in total forests began to lag behind the general socio-economic development. ${ }^{17}$ Therefore, the first Slovenian Agricultural Land Act from $1973^{18}$ (ALA 1973) introduced several measures which improved the status of (private) farmers, granting them also the statutory preemption right after agricultural organisations.

In the same year (1973), Slovenia adopted also the Act on inheritance of agricultural land and private agricultural holdings. ${ }^{19}$ This Act determined criteria forthe so called 'protected farms' and prohibited their division by inheritance so that such a farm was, in principle, taken over by one heir under conditions not representing a too heavy burden for her (what was achieved through reduction of hereditary shares of other heirs).

As the agricultural land maximum was determined in different extent for farmers than non-farmers, an individual was allowed to own more agricultural land if she was considered to be a farmer.

The ALA from 1973 defined a farmer starting from the so called 'working concept of the private ownership' 20 a farmer was a citizen who personally cultivated privatelly-owned agricultural land and gained 'important income' from the agricultural activity. Due to a great number of farms with mixed income, namely from agricultural and off-farm activities, the Act provided that the status of farmer was recognised also to an individual who owned agricultural land and his (her) family member personally cultivated agricultural land as a farmer. In principle, a farmer had to have a residence in the municipality where the agricultural land she cultivated was situated, but the administrative authority could recognise such status also to a citizen who did not live in the same municipality (Art. 4 ALA 1973).

\footnotetext{
17 Statistical Yearbook of Socialist Republic of Slovenia 1974, 124.

18 Zakon o kmetijskih zemljiščih, Official Journal of Socialist Republic of Slovenia no. 22/1973.

19 Zakon o dedovanju kmetijskih zemljišč in zasebnih kmetijskih gospodarstev (kmetij), Official Journal of Socialist Republic of Slovenia no. 26/1973.

${ }^{20}$ Kocjan 1979, 27.
} 
Non-farmers were allowed to own and (or) take on lease at most 1 ha of land in lowland and 3 ha in hilly and mountainous regions, but in no case more than $1 / 2$ ha of vineyard and $1 / 2$ ha of forest (Art. 51 ALA 1973). Non-farmers were given a 5 -year period to adapt the sufarce of their agricultural land and forest to new provisions - not only through transfer to social ownership or to agricultural organizations, but also to farmers and other individuals (Art. 115 ALA 1973).

The so called 'agricultural land communities' were typical institution of the selfgovernment system and were defined as self-governing communities, through which 'associated cultivators of agricultural land' would 'direct the agricultural land policy in each municipality' (Art. 1 ALA 1973). These communities were established by the so called agricultural and forestry organisations of the associated labour (enterprises and cooperatives with socially owned assets), municipality and localities (smaller territorial units within a municipality). They had important prerogatives in the procedures of spatial planning and legal transactions with agricultural land. However, farmers and other individuals were not directly members of these communities, but indirectly through agricultural cooperatives, localities and the municipality. ${ }^{21}$

In comparison with the former federal legislation which granted the statutory preemption right only to agricultural organisations, carrying out the agricultural activity on socially owned land, the ALA from 1973 broadened the circle of persons entitled to the statutory preemption right, including farmers and agricultural land communities.

The statutory preemption right was stipulated only for agricultural land in private property to the benefit of several preemptors, ranked in the following priority classes: (1) agricultural organisation or farmer as a tenant of the agricultural land offered for sale, (2) agricultural organisations whose agricultural land bordered to the agricultural land offered for sale (neighbouring agricultural organisations), (3) farmers whose agricultural land land bordered to the agricultural land offered for sale (neighbouring farmers), (4) agricultural land community, (5) other agricultural organisations with the agricultural land in reasonable proximity, (6) other farmers with agricultural land in reasonable proximity (Art. 19 ALA 1973).

It should be added that the the surface of socially owned agricultural land to which an agricultural organisation or agricultural land community hold the rights of use and disposal, was not limited, while a farmer or other individual who had acquired agricultural land (including through the statutory preemption right) to such an extent that the total surface of all agricultural land and forests after the purchase exceeded the prescribed agricultural land maximum, was obliged to transfer the surplus surface over the maximum into social ownership. If the maximum was exceeded by legal transactions inter vivos (for instance: sale), no compensation was paid. The compensation was guaranteed only for the surplus of agricultural land which was acquired above maximum through inheritance (Art. 17 and 18 ALA 1973).

The ALA 1973 also tried to make the provisions on agricultural land maximum more flexible. So, the agricultural land cultivated by a farmer within a production cooperation with an organisation of associated labour and the agricultural land taken into lease by an individual (not necessarily a farmer) which would have otherwise remained uncultivated was not taken into account when determining whether the land

${ }_{21}$ Čeferin 1973, 33. 
maximum was exceeded (Art. 48 and 49 ALA 1973). However, farmers and other individuals did not use these options for increasing their agricultural land in ownership or use, since the conditions for retaining the land so acquired depended on circumstances outside their control, being of a rather precarious nature.

As the ALA 1973 defined numerous holders of the statutory premption right, notifiying each preemptor individually of the intended sale would have been too heavy burden for a seller. Therefore, the Act prescribed a special procedure for notification and acceptance of the offer for sale. The owner of agricultural land offered for sale had to submit the offer in triplicate to the competent local office or to the administrative authority competent for property and legal affairs of the municipality where the agricultural land offered for sale was situated. The offer had to include the identification data of the agricultural land, the price and other terms of sale. It had to be loaded on the announcement board of the local office or municipality for fifteen days and sent to the agricultural land community. The deadline for exercising the preemption right was thirty days since the date on which the agricultural land community received the offer.

The ALA 1973 extended administrative control of contracts on sale of agricultural land. Thus, a holder of the preemption right wanting to enforce her right had to send a written statement of acceptance of the offer by registered mail not only to the seller, but also to the competent local office or, where there was no local office, to the municipal administrative authority (Art. 20 ALA 1973). The transfer of agricultural land throgh sale contract in the land registry was not possible without a certificate of the competent authority that the proceeding prescribed for the statutory preemption right had been carried out (Art. 21 ALA 1973).

\subsection{Amendments to the Agricultural Land Act (1979)}

The amendments to the ALA from 1979 (ALA 1979)22 brought several novelties regarding the status of farmer.

The requirement that a farmer should have residence in the municipality where the cultivated agricultural land was situated, was cancelled. It was replaced by the requirement of 'adequate qualification for cultivation of agricultural land' which was to be regulated by an executive regulation, issued by the agricultural ministry. This requirement did not apply to those individuals who had personally cultivated the agricultural land and abandoned the agricultural production due to their age or inability, but took care for the cultivation of their land and retained the status of farmer.

The former requirement for farmers to achieve an important income from agriculture, was replaced by a provision that that agricultural activity had to be 'a principal or complementary activity of a farmer' and quantified. According to the ALA 1979, this requirement was met if an individual gained income from agricultural activity at least in an amount corresponding to $1 / 3$ of the average salary in the municipality, or investing in agricultural activity to such an extent that the investments made would enable such value of the agricultural production (for areas that were not

22 Technically, the ALA from 1973 was amended by adopting a consolidated version of the Agricultural Land Act, Official Journal of Socialist Republic of Slovenia no. 1/1979. 
classified as the best agricultural land, other amount could be determined by municipality).

In addition, the ALA 1979 aknowledged the status of farmer also to an individual who wanted to acquire ownership right on the agricultural land and proved to the administrative authority adequate qualification and the main or complementary character of the planned agricultural production (Art. 4). This provision was substantiated as a logical concretisation of the constitutionally guaranteed free choice of employment and occupation..$^{23}$

The ALA 1979 introduced a provision that only agricultural organizations and farmers were allowed to have ownership right on the best agricultural land which was classified as the first category of agricultural land in the municipal spatial plan (Art. 10 and 58 ALA 1979). Non-farmers were obliged to adapt to this provision in 5-year period either through transfer of the agricultural land to farmers or to agricultural organizations (Art. 143 ALA 1979).

The ALA 1979 introduced two restrictions in order to prevent ciorcumvention of the preemption right (1) either through artificially high prices for sale of agricultural land or (2) through fictious deed of gifts (contracts of donation).

If a holder of preemption right considered that the price in the offer had significantly exceeded the market value of the agricultural land offered for sale, she might initiate the procedure for determining the market value of the offered land before the municipal administrative authority competent for property matters within the period for acception of the offer. The offeror was allowed to withdraw her offer within fifteen days after she was notified of the established market value of the offered agricultural land, otherwise, the holders of the preemption right were allowed to exercise their priority right of purchase at the price equal to the established market value of the land within further fifteen days. If no preemptor bought the land within the 15-days period, or if the market value was not established within the prescribed time, the offeror was allowed to sell the land to another interested party (Art. 26(2) of ALA 1979).

As non-farmers did not have the statutory preemption right, this right could be circumvented also by fictious donation contracts. The ALA 1979 limited the contractual freedom in such a way that a farmer was allowed to donate the agricultural land to a non-farmer only if the donee was her spouse, descendant or adoptive child, parent, brother or sister. For farmers, holders of protected farms, the Act provided an additional restriction since they were allowed to donate only such land which could be exceptionally inherited testamentarily by a heir who did not take over the protected farm as a whole. ${ }^{24} \mathrm{~A}$ donee could be entered in the land registry as a new owner of the agricultural land only if the competent administrative authority issued a certificate that the relevant provisions had been complied with (Art. 29 ALA 1979).

\footnotetext{
23 See Kocjan 1979, 24.

24 The object of such disposal could be only agricultural non-arable land situated in an area where the purpose of the land might be changed, Act on inheritance of agricultural land and private agricultural holdings, Art. 22.
} 
Franci Avsec

The preemption right on agricultural land in Slovenia: past developments and future challenges
Journal of Agricultural and

Environmental Law

$28 / 2020$

\subsection{Amendments to Agricultural Land Act (1986)}

The amendments of ALA in $1986^{25}$ followed by the consolidated version (ALA 1986) increased the income requirement for farmers to at least $2 / 3$ (instead of previous $1 / 3$ ) of the average salary in the municipality but allowed revenue from forestry and other activies related with agriculture to be taken into account when the income gained from agriculture was established. The amendments specified more precisely also the adequate qualification requirement. Individuals younger than 25 years met this requirement only if they had finished two-year education at agricultural secondary school. Individuals who were 25 years or older could meet the qualification requirement also by at least 5 year lasting personal cultivation of land or by passing the exam relating to programme for farmers at the secondary school level (Art. 4 ALA 1986). The transitional provisions to the amendments from 1986 stipulated that citizens who had acquired the status of farmer according to previous provisions retained such status if they cultivated agricultural land or, in case of disability or age, took care of its cultivation (Art. 156 ALA 1986).

The most important provision relating to the legal transactions of agricultural land introduced by ALA 1986 was the prohibition of division of the protected private farms inter vivos: already 13 years had already passed since the adoption of the Act on inheritance of agricultural land and private agricultural holdings (1973) when the legislator realized that if holders of protected farms were allowed to divide freely their farms before the case of inheritance, the objectives of special succession rules could hardly be achieved. Therefore, a new rule, which, in principle, prohibited protected farms to be divided through legal transactions inter vivos was added. As an exception to this prohibition, a division of a protected farm was allowed if it resulted in a formation, increase or rounding-off of other protected farms or complexes of socially owned agricultural land. In other cases, the protected farm had to be alienated as a whole (Art. 21(3) ALA 1986).

At the same time, the Act also introduced the priority right of co-owner if coowner share of other co-owner was offered for sale. This preemption right was exercised through personal notification of co-owners according to the general obligation legislation, the special procedure prescribed for exercising the preemption right by ALA was not applicable. ${ }^{26}$

The provision that non-farmers had to transfer the best agricultural land (which was classified in spatial plans as the first area of agricultural land) to agricultural organisations or farmers was cancelled (Art. 58(4) ALA 1986). The modification was explained by the difficulties to implement the cited provision in lowlands with a great share of the best agricultural land and a high share of non-farmers among the owners, because the existing ownership structure could be adjusted to the law mainly not through exchange, but through the sale of the best agricultural land owned by non-

\footnotetext{
25 Act amending the Agricultural Land Act, Official Journal of Socialist Republic of Slovenia no. $1 / 1986$.

26 Čeferin 1988, 101-123.
} 
farmers. ${ }^{27}$ The purchase would require considerable financial means of agricultural organisations and farmers, while non-farmers also preferred the land exchange to the sale with the consideration in cash, taking the inflation growth into account. ${ }^{28}$ This change was, as it will be shown, the first step towards the total abolishment of agricultural land maximums in Slovenia. However, the ALA 1986 retained the prohibition that non-farmers were not allowed to acquire the best agricultural land.

\subsection{Equal ranking of agricultural organisations and farmers as preemptors (1990)}

The Slovenian Constitutional amendments from 198929 increased the maximum of arable agricultural land for farmers from 10 to 30 hectares per holding, while the limits of agricultural arable land for farmers in hilly and mountainous regions were no more laid down by the Constitution and had to be determined by the legislation (Constitutional Amendment XXVII/2). Social, cooperative and private ownership were proclaimed to be equal ownership forms (Constitutional Amendment $\mathrm{XI} / 6)$.

The Constitutional Act Implementing the Constitutional Amendments IX to LXXXIX to the Constitution of Socialist Republic of Slovenia ${ }^{30}$ and a special act ${ }^{31}$ abolished the agricultural land communities. The tasks, rights and obligations of these communities were taken over by municipalities.

After amendments from $1990^{32}$ the ALA 1990 definitely abolished the maximum of arable land for hilly and mountainous areas explicitly stating that farmers in these areas were allowed to own agricultural arable land 'to an unlimited extent' (Art. 51 ALA 1990). At the same time, the maximum for total agricultural land and forest (in principle, 45 hectares) was completely abolished for all farmers (cancellation of the Art. 57 ALA 1990).

In line with the equal legal position of different ownership forms (Constitutional Amendment IX/6) the ALA 1990 placed agricultural organisations and farmers in principally equal position. Among farmers, however, the priority was given to those who carried out agriculture as their main activity (amended Art. 24(4)).

\footnotetext{
${ }^{27}$ Draft Act amending the Agricultural Land Act and Reporter of the SFRY Assembly and the SRS Assembly for delegations and delegates, 27.

${ }^{28}$ In the second half of the 1980s, the inflation began to accelerate. In Slovenia, the retail prince index in 1985 was 155.2, in 1986 was 179.3, Statistični letopis Republike Slovenije, 436.

${ }^{29}$ Ustavni amandmaji k Ustavi Socialistične Republike Slovenije, Official Journal of Socialist Republic of Slovenia no. 32/1989.

${ }^{30}$ Constitutional Act for of Constitutional Amendments IX to LXXXIX to the Constitution of Socialist Republic of Slovenia, Official Journal of Socialist Republic of Slovenia no. 321706/1989.

31 Act determining the tasks temporarily performed by bodies of self-governing interest communities from 1 January 1990 and establishing certain republican administrative bodies, Official Journal of Socialist Republic of Slovenia no. 42/1989, Official Journal of Republic of Slovenia no. 8/1991 and no. 27/1991.

32 Act amending the Agricultural Land Act, Official Journal of Republic of Slovenia no. 9/1990.
} 


\subsection{Extension of the preemption right and the changed priority order (1991)}

After amendments to the ALA in the next year, ${ }^{33}$ the ALA 1991 extended the preemption right to all agricultural land, including the socially owned agricultural land, and radically changed the priority order of statutory preemptors. On the first place, the priority right could be exercised by (1) a farmer or agricultural organisation as a tenant of the land offered for sale, while (2) neighbouring farmers had priority before (3) neighbouring agricultural organisations. Similarly, the next place was reserved for (4) farmers, followed by the (5) agricultural organisations, if these farmers or agricultural organisations had agricultural land in reasonable proximity. Among farmers within the same priority class, the priority was given to a farmer to whom agriculture represented the main activity (Art. 24 ALA 1991). In view of the preparations for restitution of the nationalized property and privatisation, the ALA from 1991 prohibited agricultural organisations to dispose of socially-owned agricultural land without the approval of the competent administrative authority (Art. 30 ALA 1991).

\subsection{Abrogation of provisions on agricultural land maximums, denationalisation and exclusion of agricultural land from the ownership transformation (1991- 1994)}

After the new Constitution of the Republic of Slovenia provided for no quantative limirtation of ownership right, the Constitutional Court abrogated the provisions of ALA related to the agricultural land maximum. ${ }^{34}$

While the Denationalisation Act ${ }^{35}$ from 1991 regulated the restitution of the nationalised agricultural land to former owners and their heirs either in kind or through compensation in bonds or cash, the Act on ownership transformation of enterprises $^{36}$ excluded the socially owned agricultural land from the ownership transformation of entreprises. This socially owned agricultural land and forests in former socially owned enterprises became state ownership, being managed by the National fund of agricultural land and forests. ${ }^{37}$

\footnotetext{
33 Act amending the Agricultural Land Act, Official Journal of Republic of Slovenia no. 5/1991.

34 Decision on the abrogation of Art. 51-58 of the Agricultural Land Act, Official Journal of Republic of Slovenia no. 46/1992.

35 Zakon o denacionalizaciji, Official Journal of Republic of Slovenia no. 27/1991-I, 56/1992, 13/1993, 31/1993, 24/1995, 20/1997, 23/1997, 65/1998, 76/1998, 66/2000, 66/2000, $11 / 2001,54 / 2004,18 / 2005$.

36 Zakon o lastninskem preoblikovanju podjetij, Official Journal of Republic of Slovenia no. 55/1992, 7/1993, 31/1993, 32/1994, 1/1996, 30/1998.

37 National Fund of Agricultural Land and Forest Act, Official Journal of Republic of Slovenia no. 10/1993, 1/1996, 23/1996, 91/2007, 109/2008, 8/2010, 19/2010, 56/2010, 14/2015, 9/2016. Insofar the agricultural land transferred from the social to state ownership was not restituted to former owners or their heirs, the National fund had to conclude long-term lease contracts with former enterprises transformed into commercial companies.
} 


\subsection{Abrogation of the Agricultural Land Act as a whole (1995)}

In 1995, the Constitutional Court abrogated the Agricultural Land Act as a whole since the concept of property in the Agricultural Land Act did not "allow the Constitutional Court to repeal only certain provisions, as in such a case the Act would become inconsistent." 38 According to the Art. 171 of the Constitution, the the Court determined the longest period - one year after publication of its decision - as the date when the abrogation would take effect. In such a way, the State Assembly would be able to adopt new legislation in conformity with the Constitution.

\subsection{The new Agricultural Land Act from 1996}

The preparations for a new Agricultural Land Act took longer time than one year after the Constitutional court published its decision: the abrogated Act ceased to be applicable on 13 October 1996, while the new Agricultural Land Act entered into force only 13 days later, on 26 October 1996. 39 In the meanwhile, the legal transactions with agricultural lands were practically free from all restrictions regulated by the previous Act. 40 The reason for this delay seems to lay in the erroneous conviction of the governement that the State Assembly would adopt the newly introduced bill without long discussions. In spite of strong time pressure, the deputies had controversial standpoints to the solutions foreseen by the bill which introduced additional restrictions for legal transactions with agricultural land. ${ }^{41}$ Nevertheless, the Agricultural Land Act from 1996 was finally adopted only with few amendments. Its provisions introduced some important changes also with regard to the statutory preemption right, in particular to definition of preemptors and their priority order.

\footnotetext{
${ }^{38}$ Decision on the abrogation of the Agricultural Land Act and Instructions for implementing of commassation of agricultural land, Official Journal of Republic of Slovenia no. 58/1995.

39 Zakon o kmetijskih zemljiščih, Official Journal of Republic of Slovenia no. 59/1996.

40 The transitory provisions of Art. 124(2) of the ALA 1996 provided that contracts for the transfer of ownership or for the lease of agricultural land and forests concluded between the expiry of the previous Agricultural Land Act and the entry into force of the new Act had no legal effect if they did not comply with the provisions of the new Act. However, the Constitutional court considered this provision as an intereference in the acquired rights and abrogated it: "The petitioner knew that this (namely the non-adoption of the new Act in the prescribed one-year period, added by the author) was not a systematic release of legal transactions in agricultural land, but only a delay in regulating the issue. Such a delay, however, does not justify the legislature in retroactively interferring with the general freedom of conduct as enshrined in Article 35 of the Constitution..." Decision no. U-I-340-96, http://odlocitve.usrs.si/sl/odlocitev/US18854.

${ }^{41}$ In the parliamentary debate, one deputy (Professor France Bučar) characterised the bill as 'a patchwork which would push us 20 years back in the real socialism' arguing that several restrictions were unconstitutional (what was, as it will be shown later, confirmed 5 years later by the Constitutional court), while another deputy (Mr. Ivan Oman) replicated that agricultural land legislation was something farmers had negotiated with the former authorities.

See Državni zbor Republike Slovenije, 53. izredna seja, https://www.dz$\mathrm{rs.si} / \mathrm{wps} / \mathrm{portal} /$ Home/deloDZ/seje/evidenca?mandat=I\&type=sz\&uid=38EA7ED9C74525 15C1257832004838CD
} 
Franci Avsec

The preemption right on agricultural land in Slovenia: past developments and future challenges
Journal of Agricultural and

Environmental Law

$28 / 2020$

The ALA 1996 introduced the preemption right also for the Republic of Slovenia who would exercise this right through the National fund of agricultural land and forests which had been established three years before. On the first place, the preemption right was reserved for (1) coowner(s), followed by (2) a farmer as a tenant of the agricultural land offered for sale, (3) farmers who owned, rented or otherwise used the neighbouring land, (4) other farmers owning or using agricultural land in a reasonable proximity, (5) the Republic of Slovenia, (6) the municipality on the territory of which the agricultural land was situated, and lastly (7) for an agricultural organisation which needed the agricultural land or agricultural holding for carrying out the agricultural activity if its seat was located in a reasonable proximity (Art. 21 ALA 1996). If the offer was accepted by more farmers within the same priority class, the priority was given to that one to whom the agricultural activity constituted the sole or principal activity. Agriculture was considered to be the principal activity if the crops or assets derived from this activity constituted the principal source of subsistence for a person concerned (Art. 21 ALA 1996).

The new Act retained also the provisions according to which any buyer (not only preemptors) who considered that offered price significantly exceeded the value of the land could initiate a procedure to determine the value of the agricultural land offered for sale (Art. 24 ALA 1996). Like previously, the division of protected farmers through legal transaction inter vivos was, in principle, prohibited. ALA 1996 allowed following exceptions to this prohibition: (1) if the division of a protected farm resulted in an increase, rounding up or creation of other (protected) farms or (2) if the land was alienated that was allowed to be, in case of inheritance, devised to a person who is not the heir taking over the protected farm or (3) if the land was alienated to the Republic of Slovenia or to a municipality or (4) if the owner increased or established a coownership interest in the protected farm for the benefit of the co-owner, spouse, descendant, adoptive child or his descendant, so that requirements for protected farm continued to be met after such transaction (Art. 18 ALA 1996).

In addition, the Act foresaw several grounds on which the administrative authority was obliged to refuse the approval of the transaction, for instance: (1) if the acquirer was not qualified for agricultural production or it was otherwise obvious that the acquirer would not not cultivate the acquired land as a good manager; (2) if the transaction could lead to uneconomic fragmentation of the land; (3) if the transaction would lead to an increase of the holding over 200 ha of comparable agricultural area under the Act on inheritance of agricultural holdings ${ }^{42}$, unless the land was acquired by the State or a municipality; (4) if the purchase was intended for resale; (5) if the interests of the defense were threatened, as determined by the ministry responsible for defense; (6) if the agricultural land was acquired by an individual or a legal person who did not need it to carry out the agricultural activity; (7) if the legal transaction would clearly lead to such use of the land which would be contrary to its use according to the law (Art. 19(3) ALA 1996).

\footnotetext{
42 Agricultural Holdings Inheritance Act no. 70/1995 defined 1 ha of comparable agricultural area as equal to 1 ha of fields or gardens, 2 ha of meadows or extensive orchards, 4 ha of pasture land, 0,25 ha of orchards, vineyards, or hops, 8 ha of forests, 5 ha of forest plantations or 6 ha of marshy meadows.
} 
Franci Avsec

The preemption right on agricultural land in Slovenia: past developments and future challenges
Journal of Agricultural and

Environmental Law

$28 / 2020$

\subsection{Abrogation of provisions on legal transactions with agricultural land in ALA (2002)}

In procedure for assessment of the constitutional confommity of new provisions, the Slovenian Constitutional court in 2002 abrogated the whole Chapter III of the ALA 1996 dealing with legal transactions with agricultural land so that the abrogation came into effect after one year. ${ }^{43}$ According to the Constitutional Court, neither the Government nor the State Assembly had demonstrated that stricter substantive and procedural restrictions of the ALA 1996 for legal transactions with agricultural land, were essential, adequate and proportional. ${ }^{44}$ Several grounds defined by ALA 1996 on which the administrative authority was allowed to refuse the approval of the transaction, referring, for instance, to 'obviuosness' of the fact that the acquirer 'would not cultivate the land as a good manager', to 'uneconomic fragmentation of the land,' to 'endangered defense interests,' to 'the need of an individual or a legal person to carry out agricultural activity' and to a 'clear contrary' between the intended and the prescribed purpose of agricultural land, were found to be too much indefinite and therefore inconsistent with the principle of State governed by the rule of law. ${ }^{45}$

The obstacles for approval relating to significant difference between the price and the value of the land, to intended resale of agricultural land and growth of agricultural holdings over the size of 200 hectares of comparable agricultural land, were considered to be inconsistent with a free economic initiative and unrestricted competition, guaranteed by Art. 74 of the Constitution. ${ }^{46}$ The Constitutional court did not assess 'the pre-emptive right as such because it was not contested in principle'47 Challenging of the provision which placed agricultural organisations on the last place in priority order, was deemed by judges not to be substantiated: "These organisations are still the preferred beneficiaries. In the general interest of strengthening and rounding up small and medium-sized (family) farms, the legislator clearly found good enough reasons to determine the preferential entitlement of the neighbouring farmer or a nearby farmer, but not of the agricultural organisation, before the Fund." 48 The Constitutional court ascribed great importance to the preemption right of the National fund of agricultural land and forests what could enable "a high-capacity state fund to exercise a sovereign public interest in any eventual change of ownership of agricultural land: by exercising its preemption right, it can (at an officially established price) prevent any passage of agricultural land into inappropriate hands, ..."49

43 Decision repealing Chapter III of the Agricultural Land Act with one year suspension deadline, Official Journal of Republic of Slovenia no. 27/2002.

${ }_{44}^{4}$ Ibid. para. 4, 8, 9, 17 and 26.

45 Ibid. para. 26, 31 and 32.

${ }^{46}$ Ibid. para. 33 and 34.

47 Ibid. para. 23.

48 Ibid. para. 36. However, the Constitutional court seems to have overlooked that after the abrogation of land macimums for private ownership, no regulation obliged a family farm to transform itself into an agricultural organisation (for instance, company) even if it exceeded a small or medium size.

${ }^{49}$ Ibid para. 23. 
Franci Avsec

The preemption right on agricultural land in Slovenia: past developments and future challenges
Journal of Agricultural and

Environmental Law

$28 / 2020$

\subsection{New provisions in place of the abrogated ones (2003)}

The provisions of the Agricultural Land Act regulating legal transactions of agricultural land ceased to be applicable on 28 March 2003, while the new provisions instead of the abrogated ones entered into force only on 9 April 2003.50 Once again, the legal transactions could be concluded without restrictions and administrative control for 11 days, but the amendments to the ALA in 2003 no more provided for their retroactivity. The amended Act from 2003 (ALA 2003) introduced some changes in the priority order of preemptors. While (1) co-owners retained the first place, (2) farmers as owners (and no more only users) of agricultural land bordering to the land offered for sale climbed one place higher, and (3) the tenant of the agricultural land offered for sale slipped from the second to the third place, ${ }^{51}$ being followed (4) by 'other farmers' (NB: without requirement for owning land in a reasonable proximity) and (5) agricultural organisations and (newly) individual entrepreneurs needing agricultural land or holding for carrying out agricultural or forestry activity, before (7) the National fund of agricultural land and forests which - contrary to the opinion of the Constitutional court - occupied the last place among statutory preemptors (Art. 23(1) ALA 2003).

The ALA 2003 also supplemented the priority order for farmers from the same priority class who accepted the offer. The previous solution according to which the right to purchase in such a case was first given to a farmer whose agricultural activity was her sole or principal activity, then to a farmer who cultivated the land herself and in the last line, to a farmer designated by the seller, was complemented by a special provision for the sale of state-owned agricultural land where the seller had to designate a buyer by the method of public auction (Art. 23(2) ALA 2003). In the view of the approaching accession of Slovenia to the European Union based on free movement of goods, services, persons and capital, the ALA 2003 changed also the definition of farmer who needed to be an individual and no more a (domestic) citizen (Art. 24 ALA 2003). According to the new provisions, the local administrative authority where agricultural land offered for sale was situated, had to publish the offer for sale not only on the notice board, but also on the single national portal of the E-government (Art. 20 ALA 2003).

\subsection{Amendments to ALA (2011)}

The modifications of the Agricultural Land Act from $2011^{52}$ restricted the conclusion of gift contracts. If the object of donation contract was agricultural land, such a contract may be concluded only with a spouse or partner and close relatives of

50 Act amending the Agricultural Land Act, Official Journal of Republic of Slovenia no. $36 / 2003$.

${ }^{51}$ In case where state-owned agricultural land was leased to agricultural organisation, this change gave priority to the the bordering farmer before the agricultural organisation as a tenant (of the previuosly socially-owned agricultural land).

52 Act amending the Agricultural Land Act, Official Journal of Republic of Slovenia no. $43 / 2011$. 
the donor, with the State or a municipality or with a head of agricultural holding who has acquired funds on the basis of the Rural Development Programme as a young farmer and no more than 5 years have elapsed from her take-over of the holding (Art. 17 a of ALA 2011). As the first order of priority could be circumvented so that the owner established a co-ownership share to the benefit of the prospective buyer, the legislator stipulated that only the whole ownership right or the existing co-ownership share of agricultural land might be object of a donation contract to the benefit of a young farmer who has taken over a farm in last 5 years or object of a sale contract regardless of the buyer (Art. 17a ALA 2011).

\subsection{Amendments to ALA (2016)}

After amendmends from $2016^{53}$ the ALA 2016 brought several precisations relating to the procedure of exercising of the preemptive right which took over also the established case-law. The new provisions stipulate that the owner who submitted the offer to administrative authority with the intention to sell agricultural land, forest or farm, is deemed to have authorized the administrative unit for receipt of a written statement of acceptance of the offer. The Act took over also the legal opinion of principle, issued in 2012 by the Supreme Court: ${ }^{54}$ when the administrative authority receives a statement of acceptance of the offer, the legal transaction is deemed to be concluded under a suspensive condition of approval by the administrative authority (Art. 20 and 21 ALA 2016).

The ALA 2016 extended, although very cautiously, the list of exemptions from obtaining the approval of the administrative authority. The administrative authority may issue a confirmation that the approval is not necessary in cases of acquisition of agricultural land: (1) in the context of agrarian operations; (2) between spouses or partners, the owner and his legal heirs, if the agricultural land is not a part of a protected farm; (3) among co-owners, where agricultural land, forest or farm is owned by two or more co-owners and the contract is concluded by all co-owners; (4) through a contract of annuity for life; (5) through gift in the event of death (mortis causa) or contract of delivery; (6) which has a maximum surface area of $1000 \mathrm{~m} 2$ and on which a less demanding or demanding building has been constructed if a final building permit has been issued for such a building; (7) through a gift contract inter vivos, among contractual parties in accordance with the Act; (8) through a contract of subsistence, or a divorce of such a contract in accordance with the law governing the obligations; (9) if the agricultural land is transferred for construction of certain objects in the public interest or objects intended for agricultual activity or contracts are concluded with municipality in order to exchange agricultural land for building land or where a municipality buys agricultural land in order to exchange it for a building land of the neighbouring farmer as the second preemptor etc. (Art. 19 ALA 2016).

53 Act amending the Agricultural Land Act, Official Journal of Republic of Slovenia no. $27 / 2016$.

54 Vrhovno sodišče RS 2012. 
Franci Avsec

The preemption right on agricultural land in Slovenia:

Journal of Agricultural and Environmental Law past developments and future challenges

$28 / 2020$

Table 1: Holders of statutory preemption right and their ranking in general agricultural land legislation in Slovenia 1962-2020

Note: For better transparency, the table does not resume rules for additional ranking among farmers within the same priority class)

\begin{tabular}{|c|c|c|c|c|c|c|c|}
\hline \multirow[b]{2}{*}{ Rank } & \multicolumn{7}{|c|}{ Name of the Act, State, Number and Year of the Official Journal } \\
\hline & $\begin{array}{l}\text { Agricultural Land } \\
\text { Exploitation Act, } \\
\text { FPRY no. 53/1962 }\end{array}$ & $\begin{array}{c}\text { Agricultural } \\
\text { Land Act, } \\
\text { SRS no. 22/1973 } \\
\end{array}$ & $\begin{array}{c}\text { Agricultural } \\
\text { Land Act, } \\
\text { SRS no. 1/1986 } \\
\end{array}$ & $\begin{array}{c}\text { Agricultural } \\
\text { Land Act, } \\
\text { SRS no. 9/1990 }\end{array}$ & $\begin{array}{c}\text { Agricultural } \\
\text { Land Act, } \\
\text { RS no. 5/1991 }\end{array}$ & $\begin{array}{c}\text { Agricultural } \\
\text { Land Act, } \\
\text { RS no. 59/1996 } \\
\end{array}$ & $\begin{array}{c}\text { Agricultural } \\
\text { Land Act, } \\
\text { RS no. 36/2003 }\end{array}$ \\
\hline 1 & $\begin{array}{c}\text { Agricultural } \\
\text { organisations }\end{array}$ & $\begin{array}{c}\text { Agricultural } \\
\text { organisation or farmer } \\
\text { as a tenant }\end{array}$ & $\begin{array}{c}\text { Farmer as a co- } \\
\text { owner }\end{array}$ & Farmer as co-owner & $\begin{array}{c}\text { Farmer or } \\
\text { agricultural } \\
\text { organisation as a } \\
\text { tenant }\end{array}$ & Co-owner & Co-owner \\
\hline 2 & & $\begin{array}{l}\text { Neighbouring } \\
\text { agricultural } \\
\text { organisations }\end{array}$ & $\begin{array}{c}\text { Agricultural } \\
\text { organisation or } \\
\text { farmer as a tenant }\end{array}$ & $\begin{array}{c}\text { Neighbouring } \\
\text { agricultural } \\
\text { organisations and } \\
\text { neighbouring farmers }\end{array}$ & $\begin{array}{l}\text { Neighbouring } \\
\text { farmers }\end{array}$ & Farmer as a tenant & $\begin{array}{l}\text { Neighbouring farmers } \\
\text { (as owners of the } \\
\text { bordering land) }\end{array}$ \\
\hline 3 & & Neighbouring farmers & $\begin{array}{l}\text { Neighbouring } \\
\text { agricultural } \\
\text { organisations }\end{array}$ & Municipality & Municipality & $\begin{array}{c}\text { Neighbouring } \\
\text { farmers (as } \\
\text { owners, tenants or } \\
\text { users of the } \\
\text { neghbouring land) }\end{array}$ & $\begin{array}{l}\text { A tenant of the } \\
\text { agricultural land }\end{array}$ \\
\hline 4 & & $\begin{array}{l}\text { Agricultural land } \\
\text { community }\end{array}$ & $\begin{array}{l}\text { Neighbouring } \\
\text { farmers }\end{array}$ & $\begin{array}{c}\text { Agricultural } \\
\text { organisations and } \\
\text { farmers with } \\
\text { agricultural land in } \\
\text { reasonable proximity }\end{array}$ & $\begin{array}{l}\text { Other farmers with } \\
\text { agricultural land in } \\
\text { reasonable proximity }\end{array}$ & $\begin{array}{c}\text { Other farmers (as } \\
\text { owners, tenants or } \\
\text { other users) of the } \\
\text { land in reasonable } \\
\text { proximitty }\end{array}$ & Other farmers \\
\hline 5 & & $\begin{array}{l}\text { Other agricultural } \\
\text { organisations with } \\
\text { agricultural land in a } \\
\text { reasonable proximity }\end{array}$ & $\begin{array}{l}\text { Agricultural land } \\
\text { community }\end{array}$ & & $\begin{array}{l}\text { Other agricultural } \\
\text { organisations with } \\
\text { agricultural land in } \\
\text { reasonable proximity }\end{array}$ & Municipality & $\begin{array}{c}\text { Other agricultural } \\
\text { organisations or } \\
\text { individual } \\
\text { entrepreneurs } \\
\text { neeeding agricultural } \\
\text { land }\end{array}$ \\
\hline 6 & & $\begin{array}{l}\text { Other farmers with } \\
\text { agricultural land in } \\
\text { reasonable proximity }\end{array}$ & $\begin{array}{l}\text { Other agricultural } \\
\text { organisations with } \\
\text { agricultural land in } \\
\text { reasonable proximity }\end{array}$ & & & $\begin{array}{l}\text { National fund of } \\
\text { agricultural land } \\
\text { and forests }\end{array}$ & $\begin{array}{l}\text { National fund of } \\
\text { agricultural land and } \\
\text { forests }\end{array}$ \\
\hline 7 & & & $\begin{array}{l}\text { Other farmers with } \\
\text { agricultural land in } \\
\text { reasonable proximity }\end{array}$ & & & Municipality & \\
\hline 8 & & & & & & $\begin{array}{l}\text { Agricultural } \\
\text { organisation } \\
\text { having seat in } \\
\text { reasonable } \\
\text { proximity }\end{array}$ & \\
\hline
\end{tabular}




\section{Other preemption rights that relate or may relate to agricultural land}

\subsection{Subsidiary application of the ALA preemption right}

The ALA explicitly states that preemptors exercise their priority right according to its provisions if other legislation does not provide otherwise. This provision is applied so that special provisions derogate the general ones (section 3.2) or preemptors defined by special provisions have priority before preemptors according to the ALA (section 3.3).

\subsection{Two other preemptive rights in agricultural land legislation}

The Agricultural Communities Act and the Agricultural Holdings Inheritance Act regulate two special preemption rights that relate to agricultural land.

The Agricultural Communities Act from $2015^{55}$ defines the legal status and activities of the so called agricultural communities as associations of individuals and legal persons for joint use of commonly owned agricultural land (for instance, Alpine pastures). The Act foresees, inter alia, a special preemption right in a case when a member of agricultural community offers her interest in the common land property for sale. In such a case, the preemption right may be exercised by several preemptors in the following order: (1) the agrarian community the member of which is the offeror, provided that the a decision to purchase the share is adopted by the general meeting with at least by two-thirds majority of all members' votes (the purchase by the agricultural community means that the co-ownership right is acquired by all members in proportion to their shares in common property); (2) a member of the agrarian community (if several members who are co-owners exercise the pre-emptive right, the buyer shall be selected by the seller); (3) a so called accession member ${ }^{56}$ of the agrarian community (the priority right of several accession members is exercised according to the chronological order of their admission to the accession membership); (4) other individual who resides in the municipality where the agricultural land subject to sale is situated (in case where several individuals accept the offer, the buyer is selected by the seller).

For procedures relating to the preemption right under this Act the adequate provisions of ALA are correspondingly applicable (Art. 42).

\footnotetext{
55 Zakon o agrarnih skupnostih, Official Journal of Republic of Slovenia no. 74/2015.

56 The accession member is a person which is interested in membership in the agricultual community and admitted as such by the general meeting of the agricultural community. Accession member has no rights relating to the management of common property but is entitled to exercise a statutory preemption right in case when an ordinary member sells her share in order to become an ordinary member, Agricultural Communities Act, Art. 11.
} 
The second preemption right regarding the agricultural land is stipulated by the the Agricultural Holdings Inheritance Act ${ }^{57}$, according to which a so called protected farm may be inherited, in principle, only by a sole heir and the inheritance rights of forced heirs are reduced to cash value of their compulsory portions (with certain exceptions).

If a heir who took over the protected farm sells the farm or a part of it, other coheirs may exercise a preemption right (Art. 19).

\subsection{Special preemption rights on agricultural land in other legislation}

In some cases, agricultural or other land (for instance, forest, building land) has a special purpose determined by the legislation concerning nature conservation, water, cultural heritage, spatial planning and war grave sites.

The Nature Conservation Act ${ }^{58}$ stipulates that the State or a local community has a preemption right relating to real estate located in protected areas for which the State or local community has adopted the instrument of protection. This preemption right has priority before preemption rights according to agricultural land, forest, water and building land legislation. If the State or local community does not exercise their first preemption right, the preemption right laid down by the agricultural land, forest, water and land building legislation may be exercised so that within the same category of preemptors, priority is given to those who already own the real estate of the same type located in the protected area (Art. 84), what modifies the priority order laid down in the ALA.

According to the Water Act, ${ }^{59}$ the local community which is going to proclaim costal land or part of it as a natural aquatic public good has the best preemption right on such coastal land of inland waters (Art. 16), while the State has the best preemption right relating to other coastal land of inland waters (Art. 22). In both cases, the best priority right may be exercised regardless 'of provisions which regulate the priority order of preemptors in other legislation.'

The Cultural Heritage Protection Act $^{60}$ regulates the priority right of the State or a local community to purchase a monument of national or local importance or property in area of influence of an immovable monument of such importance, if so stipulated in the legal act proclamating the monument. If the State does not exercise its premption right on the monument or adjacent area of influence, this right may be exercised by the local community (Art. 62).

\footnotetext{
57 Zakon o dedovanju kmetijskih gospodarstev, Official Journal of Republic of Slovenia no. 70/1995, 54/1999, 30/2013.

58 Zakon o ohranjanju narave, Official Journal of Republic of Slovenia no. 96/2004, 61/2006, 8/2010, 46/2014, 21/2018, 31/2018.

59 Zakon o vodah, Official Journal of Republic of Slovenia no. 67/2002, 2/2004, 41/2004, 57/2008, 57/2012, 100/2013, 40/2014, 56/2015.

${ }^{60}$ Zakon o varstvu kulturne dediščine, Official Journal of Republic of Slovenia no. 16/2008, 123/2008, 8/2011, 90/2012, 111/2013, 32/16, 21/2018.
} 
The Spatial Planning Act ${ }^{61}$ from 2017 introduced a special preemption right of the State or local community on land, which meets certain requirements (for instance, agricultural land for constructing public utility infrastructure and facilities used for protection against natural and other disasters) and is determined by the State or the local community. This preemption right does not apply in some cases (in case of sale contract between spouses or close lineal relatives), but has priority before the preemption right determined by the ALA. The seller must repeat the offer to the State or local community if two months have passed since the previous offer, although the price and other terms of sale remain unchanged (Art. 189-191).

The War Grave Sites Act ${ }^{62}$ stipulates that the State has the preemption right if the land where a war grave site is situated, is offered for sale (Art. 25). The standpoint of theory is that the preemption right of the State in this case is 'the most special one,' having absolute priority before other preemption rights. ${ }^{63}$

Table 2: Special preemption rights in the Slovenian legislation that may relate to agricultural land

\begin{tabular}{|c|c|c|c|c|}
\hline $\begin{array}{l}\text { The name and } \\
\text { article of the } \\
\text { Act }\end{array}$ & $\begin{array}{c}\text { Immovable to which } \\
\text { the statutory } \\
\text { preemption right } \\
\text { relates }\end{array}$ & $\begin{array}{l}\text { Holder of the } \\
\text { preemption } \\
\text { right }\end{array}$ & $\begin{array}{l}\text { Notification of the } \\
\text { sale offer and } \\
\text { period for exercise } \\
\text { of the preemption } \\
\text { right }\end{array}$ & $\begin{array}{l}\text { Relationship with } \\
\text { the preemption } \\
\text { right according to } \\
\text { the ALA }\end{array}$ \\
\hline $\begin{array}{c}\text { Nature } \\
\text { Conservation } \\
\text { Act, Art. } 84\end{array}$ & $\begin{array}{c}\text { Real estate in protected } \\
\text { areas }\end{array}$ & $\begin{array}{l}\text { State or local } \\
\text { community } \\
\text { which adopted } \\
\text { the instrument } \\
\text { of protection }\end{array}$ & $\begin{array}{c}\text { Individual } \\
\text { notification of the } \\
\text { ministry and } \\
\text { administrator of the } \\
\text { protector area, } 30 \\
\text { days }\end{array}$ & $\begin{array}{l}\text { The preemption right } \\
\text { according to the ALA } \\
\text { applies subordinately } \\
\text { and the priority order } \\
\text { is modified }\end{array}$ \\
\hline $\begin{array}{l}\text { Water Act, Art. } \\
17 \text { and } 22\end{array}$ & $\begin{array}{l}\text { Coastal land of inland } \\
\text { waters }\end{array}$ & $\begin{array}{l}\text { Local } \\
\text { community and } \\
\text { State }\end{array}$ & $\begin{array}{l}\text { According to the } \\
\text { ALA, the } \\
\text { municipality is } \\
\text { additional } \\
\text { preemptor with the } \\
\text { best priority order }\end{array}$ & $\begin{array}{l}\text { The local community } \\
\text { or the State is the } \\
\text { preemptor of the first } \\
\text { priority (modification } \\
\text { of priority order) }\end{array}$ \\
\hline $\begin{array}{c}\text { Cultural Heritage } \\
\text { Protection Act, } \\
\text { Art. } 62\end{array}$ & $\begin{array}{l}\text { A monument of } \\
\text { national or local } \\
\text { importance, and } \\
\text { immovable property in } \\
\text { the area of influence of } \\
\text { an immovable } \\
\text { monument of national } \\
\text { or local importance }\end{array}$ & $\begin{array}{l}\text { State and local } \\
\text { community }\end{array}$ & $\begin{array}{c}\text { Individual } \\
\text { notification of the } \\
\text { ministry or } \\
\text { municipality, } 30 \text { days } \\
\text { for the State, } 30 \\
\text { days for the } \\
\text { municipality }\end{array}$ & $\begin{array}{l}\text { The preemptive right } \\
\text { according to the ALA } \\
\text { applies subordinately }\end{array}$ \\
\hline $\begin{array}{l}\text { Spatial Planning } \\
\text { Act, Art. 189-191 }\end{array}$ & $\begin{array}{l}\text { Real estate in areas } \\
\text { which meet certain } \\
\text { requirements laid down } \\
\text { by the Act and are } \\
\text { determined by the State } \\
\text { or a local community }\end{array}$ & $\begin{array}{l}\text { State or local } \\
\text { community }\end{array}$ & $\begin{array}{c}\text { Individual } \\
\text { notification of the } \\
\text { ministry or } \\
\text { municipality, } 15 \text { days }\end{array}$ & $\begin{array}{l}\text { The preemptive right } \\
\text { according to the ALA } \\
\text { applies subordinately }\end{array}$ \\
\hline $\begin{array}{c}\text { War Grave Sites, } \\
\text { Art.-25 }\end{array}$ & $\begin{array}{c}\text { The land property } \\
\text { where a grave site is } \\
\text { situated }\end{array}$ & State & $\begin{array}{c}\text { Individual } \\
\text { notification of the } \\
\text { competent ministry, } \\
2 \text { months }\end{array}$ & $\begin{array}{l}\text { The preemption right } \\
\text { according to the ALA } \\
\text { applies subordinately }\end{array}$ \\
\hline
\end{tabular}

${ }^{61}$ Zakon o urejanju prostora, Official Journal of Republic of Slovenia no. 61/2017.

62 Zakon o vojnih grobiščih, Official Journal of Republic of Slovenia no. 65/2003, 72/2009, $32 / 2017$.

63 Tratnik 2010, VI. 


\section{Draft Act on modifications and amendments of certain laws concerning agricultural land policy from 2019}

In spring 2019, the Slovenian Ministrty of agriculture, forestry and food launched a public consultation on a Draft Act, which contained several proposals for amending certain acts dealing with agricultural land policy, ${ }^{64}$ including the ALA.

The Draft Act foresaw a certain release from restrictions connected with the legal transfer of agricultural land.

Firstly, according to the Draft Act, the owner could, under well defined conditions, sell agricultural land without offering it first to the statutory preemptors if the buyer is a head of agricultural holding who is domiciled or established either in the same municipality where the agricultural land offered for sale is situated or in a neighbouring municipality for at least 5 years before the conclusion of the contract and: (1) has been included in compulsory pension, disability and health insurance on the basis of agricultural activity for at least twelve months and entered in the Register of agricultural holdings (RAH) continuously for at least five years before the date of conclusion of the contract, or (2) has obtained funds from the rural development program as a young farmer, if no more than five years have passed since the decision on the aid became final or she is between 18 and 40 years old and manages at least 6 ha and no more than 80 ha of comparable agricultural land ${ }^{65}$, or (3) manages at least 6 ha and no more than 80 ha of comparable agricultural land and has been registered in the RAH continuously for at least five years before the date of conclusion of the contract.

This proposal leads to a conclusion that exemption from the statutory preemption right would apply only to contracts for sale of agricultural land between local heads of agricultural holdings (from the same or two neighbouring municipalities), provided that a buyer meets three additional substantial criteria: professional status (social insurance based on agricultural activity, point 1), young age and/or certain (above-average) size of buyers' holding - up to 80 ha of comparable agricultural land (point 2 and 3). The sellers or buyers could lawfully avoid formalities connected with the statutory preemption right, the workload for administrative authorities would decrease, but the seller's choice of a buyer would be still be restricted.

On the other hand, the Draft Act foresaw the following order of statutory preemptors: (1) co-owner (natural or legal person); (2) National Agricultural Land and Forest Fund on behalf of the Republic of Slovenia; (3.)head of agricultural holding (individual or legal person) who is owner of the agricultural land bordering on the land

64 Act Amending and Supplementing Certain Laws in the Field of Agricultural Land Policy

65 According to the Draft Act, the calculation of comparable agricultural land for different uses would be made through conversion factors according to which 1 hectar (ha) of agricultural land would be equal to 1 ha of arable land, 2 ha of grassland, 0,25 hectar of permanent crops, 0,1 ha of greenhouses and 8 ha of forest. These conversion factors were taken from the Governmental Decree on the sub-measure setting up support to kick-start the operations of young farmers pursuant to the Rural Development Programme of the Republic of Slovenia 2014-2020, Uredba o izvajanju podukrepa pomoč za zagon dejavnosti za mlade kmete iz Programa razvoja podeželja Republike Slovenije za obdobje 2014-2020, Official Journal of Republic of Slovenia no. 55/2015, 38/2016, 84/2016, 19/2017, 66/2018, 50/2019. 
offered for sale and has been entered in the RAH continuously for at least 5 years before the date of acceptance of the offer; (4) head of agricultural holding (individual or legal person) who: has obtained rural development programme (RDP) funding as a young farmer if no more than 5 years have elapsed since the decision granting the aid became final or if she is between 18 and 40 years old and manages at least 6 ha and no more than 80 ha comparable agricultural land, and has been residing in the same municipality where the agricultural land being sold is located or in a neighboring municipality, for at least 5 years before the date of acceptance of the offer; (5) head of agricultural holding (individual or legal person) who manages at least 6 ha and no more than 80 ha of comparable agricultural land, or is, as the head or the deputy head of an agricultural holding, compulsory insured for pension, disability and sickness on the basis of agricultural activity and: has been residing in the same municipality in which the land being sold is located or in a neighbouring municipality for at least 5 years before the date of acceptance of the offer, and has been registered in the RAH continuously for at least 5 years before the date of acceptance of the offer; (6) a head of agricultural holding (individual or legal person) who has been residing in the same municipality where the agricultural land subject to sale is located or in the neighbouring municipality for at least 5 years before the date of acceptance of the offer and has been registered in the RAH continuously for at least 5 years before the date of acceptance of the offer; (7) head of an agricultural holding (individual or legal person) registered in the RAH continuously for at least 5 years before the date of acceptance of the offer.

The most obvious change proposed for statutory preemption right is surely a strengthened role of the National Agricultural Land and Forests Fund, which would climb from the last place up to the second place (in case of co-ownership of the agricultural land) or even to the first place (in case of individed ownership). In this respect, the drafters seem to have followed the recommendation of the Constitutional court, which, while assessing the (un)constitutionality of the Chapter III of the ALA in 2002, considered that the preemption right of the National Fund could provide public interest in all cases of intended change of agricultural land ownership (through sale contracts). 66

A substantially higher ranking of the National fund on one side and a large number of subsequent preemptors (practically all heads of agricultural holdings registered for at least 5 years) raise the question about the future policy of the National fund in acquiring agricultural land and management of the land so acquired (selling or letting it out on lease). The engagement of the National fund would surely depend on the extent to which sale contracts would be concluded among local heads of agricultural holdings without preemption right being applied. A wider engagement of the State as a statutory preemptor of the first or second rank would certainly require a considerable higher capital injection in the National fund and a substantial change of its legal and program documents.

66 Decision repealing Chapter III of the Agricultural Land Act with one year suspension deadline, 23. 
Apart from the co-owner and the National fund on the first or the second place in the proposed priority order, the Draft Act linked the preemption right of other beneficiaries either to their registration in the $\mathrm{RAH}$ for at least 5 years (such a registration is obligatory for any agricultural holding which applies for financial aid or any other measure of agricultural policy $)^{67}$ or, alternatively, to their status of young farmer who has received the farm start-up and development aid in the last 5 years or acquired agricultural holding of certain size, the proposed provisions would link the preemption right closer to the (beneficiaries of the) current agricultural policy.

While at least 5-years lasting registration in the RAH would suffice for a statutory preemption right of the neighbouring owner ranked on the third place, the next (fourth) priority class would be reserved for young farmers if they reside in the close proximity to the agricultural land put on sale and have obtained a start-up and development aid or manage a farm of certain size.

In the next three priority classes the number of requirements gradually decrease. Thus, heads of agricultural holdings meeting 3 requirements: (1) certain size of a farm or compulsory social insurance for pension and disability on the basis of agricultural activity; (2) residence close to the agricultural land put on sale and (3) continuos registration in the RAH for at least 5 years, would be ranked in the fifth place, followed by heads of agricultural holdings who meet only the second and the third of the three requirements mentioned, while the seventh place would be occupied by heads of agricultural holdings meeting only the last requirement (being entered in the RAH continuosly for at least 5 years).

If we compare the conditions for sale of agricultural land between local heads of agricultural holdings and the priority order of statutory preemptors, we can see that the conditions for a local buyer who would be allowed to buy agricultural land without preemption right being exercised, correspond to the requirements for statutory preemptors on the fourth and the fifth place.

According to the ALA in force, two or more members on the same holding may be farmers and may exercise preemption right as farmer neighbours. The Draft Act, however, reserves the preemption right for the neighbouring owner only if she is a head of agricultural holding. Summing up, the proposed new regulation of the preemption right would prefer heads of agricultural holdings who have been uninterruptedly registered in the RAH and young farmers if they already manage a considerable surface of agricultural land. New entrants would practically have no chance to meet the requirement of uninterrpupted registration in the RAH for 5 years (this condition may prove to be too onerous in some life situations also for preemptors). They would be able to buy agricultural land only if no other preemptor exercised her priority right. However, such cases would be rare given a (too) wide circle of preemptors.

${ }^{67}$ Agricultural Act Official Journal of Republic of Slovenia no. 45/2008, 57/2012, 90/2012, 26/2014, 32/2015, 27/2017, 22/2018, 141. 
Franci Avsec

The preemption right on agricultural land in Slovenia: past developments and future challenges
Journal of Agricultural and

Environmental Law

$28 / 2020$

According to the Draft Act, the prohibition to divide a protected farm inter vivos would be cancelled since 'it has not brought expected results'. ${ }^{68}$ After the Constitutional Court had ruled in 2002 that the protection of certain farms against division through legal transactions inter vivos was incompatible with the principle of the social state (Art. 2 of the Constitution) insofar as it prevented the holder of such a farm to provide herself a social security through a contract of annuity for life, the ALA 2003 explicitly allowed division of protected farms by contracts of such type ${ }^{69}$. However, the social security of a farmer could be assured also through other contracts, for instance a contract of subsistence, which, however, are covered by the prohition to divide a protected farm..$^{70}$ Besides, an additional exception to the prohibition to divide a protected farm was introduced in 2003: if the division of a protected farm leads to an increase or rounding-up of an unprotected farm (Art. 18 of the ALA). The principle that protected farms may not be divided through legal transactions inter vivos, seems to be, due to rather inconsistent and casuistic exemptions, too complex and inefficient in practice.

It was interesting that the Draft Act contained only a scarce explanation of the proposed new provisions, with no analysis of the present state and reasons for proposed changes, which are obligatory elements for a bill in a legislative procedure. ${ }^{71}$

Although the public discussion of the Draft Act was closed at the end of May 2019, no new document has been published on this issue until the end of May 2020.

\section{Conclusion}

The statutory preemption right is an important tool for regulation of agricultural land transactions in accordance with the aims agricultural land policy as it may direct the transfer of agricultural land to those acquirers where the agricultural land would be used most sustainably from the economical, social and environmental point of view.

The Slovenian legislation contains several preemption rights relating to agricultural land. They are regulated by agricultural land law and other legislation.

General provisions about preemption right on agricultural land with numerous preemptors who may be individuals or legal entities of private or public law and are ranked in several priority classes, are defined by the Agricultural Land Act. Special provisions regulate statutory preemption right on agricultural land in two cases: among coheirs of the so called protected farm according to the Agricultural Holdings Inheritance Act as well as in a case where a member of agricultural community sells her share in the common land property according to the Agricultural Communities Act.

\footnotetext{
68 Zakon o spremembah in dopolnitvah določenih zakonov na področju kmetijske zemljiške politike 2019.

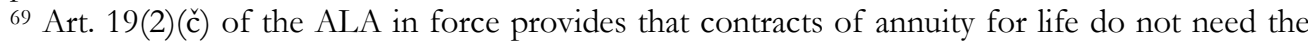
approval of the administrative authority.

70 Art. 19(2)(g) of the ALA in force exempts the contracts of subsistence from the approval requirement only if they are conform with the principle that a protected farm may not be divided.

${ }^{71}$ See Rules of Procedure of the National Assembly, Official Journal of Republic of Slovenia no. 92/2007, 105/2010, 80/2013, 38/2017, Art. 115(3).
} 
The preemption rights on real estate in legislation concerning spatial planning, nature conservation, water, cultural heritage and war grave sites, may refer, inter alia, also to agricultural land. According to the legislation in these areas, the preemptors are the State or a local community. It is interesting that most statutory preemption rights which are regulated outside the agricultural land legislation, but may relate to agricultural land, are explicitly granted priority before the statutory preemption right according to the Agricultural Land Act. In such cases the preemptive right according to Agricultural Land Act is not excluded, but may be exercised only subordinately, if the first preemptor (the State or local community) did not exercise its right.

Therefore, the statutory preemptive rights relating to agricultural land pursue various purposes which reflect the multifunctionality of agricultural land. Namely, if non-productive functions of agricultural land prevail over the productive ones, it is logical that the eventual statutory preemption right provided by the corresponding nonagricultural legislation has priority before that provided by the Agricultural Land Act. The scope of statutory preemption right is limited, even if we observe this right only from the standpoint of the Agricultural Land Act. Namely, a statutory preemption right may be exercised only in case where agricultural land is offered for sale. Although a sale contract is typical for market economy, in agriculture characterised by numerous family farms, as it is the case of Slovenia, the ownership right on the agricultural land may be and is, to a great extent, transferred to other person also through other transactions, including exchange contracts (528-529 Obligation Code, OC), contracts of donation (Art. 533-556 OC), contracts on delivery and distribution of property (Art. 546-556 OC), contracts of annuity for life (Art. 557-563 OC), contracts of subsistence (Art. 564568 OC) and other nominate and innominate contracts. Although the legislator limited the circle of persons who may be donees of agricultural land, a person who intends to alienate agricultural land may still choose other contract types, where the choice of the acquirer is not limited.

As the preemptors of agricultural land are not individually notified of the intended sale by the offerer, it can happen that one or more preemptors are not informed on time to exercise their right. Although the offers have been, since the amendments to ALA in 2003 entered into force, ${ }^{72}$ published on the eGovernment ('euprava') as public portal of the Republic of Slovenia for citizens, the information problem may still be significant as more than 80 offers may be published daily and the deadline for exercising the right is only 30 days after the offer was published.

A third problem which may limit the exercise the preemption right is financial: if the preemptor does not have (sufficient) funds available to pay the price determined in the offer, the preemptive right will not be realised. The problem is exacerbated if the price in the offer is set on a such a level that it can be considered, on the basis of objective and non-discriminatory criteria, as excessively speculative. Several legal systems in Europe provide for a possibility to review the price in the sale offer addressed to statutory preemptors if this price unreasonably deviates from the value of

${ }^{72}$ Zakon o spremembah in dopolnitvah zakona o kmetijskih zemljiščih, Official Journal of Republic of Slovenia no. 36/2011. 
the agricultural land. ${ }^{73}$ Although the Slovenian Constitutional court, as it could be understood from a lapidarily formulated grounds for its decision abrogating the entire Chapter III of the ALA 1996, had been of the opinion that all statutory preemptors (but not other buyers) of agricultural land had to be be well protected against unreasonably high prices, ${ }^{74}$ the legislator thereafter abolished provision on price control for all sale transactions with agricultural land.

The Slovenian legal theory has so far critised some provisions in Agricultural Land Act regulating preemption right on agricultural land. First, the present preemption right seems to be defined too widely since it is granted practically to all individuals in the country and other EU Member States who fulfill the requirements for farmer and to all agricultural organisations and individual entrepreneurs who need agricultural land for their agricultural production. The Act provides no criteria whether the inclusion of agricultural land concerned in the agricultural holding of 'other farmer' (than neighbour) as a preemptor would be economically feasible at all: hypotetically, a tulip grower from the Netherlands may exercise her statutory preemption right on olive grove on the Slovenian seaside. ${ }^{75}$ The proposed changes of the statutory preemption right in the Draft Act from 2019 would not provide a satisfactory solution for this problem, as they still foresaw the statutory preemption right for any head of agricultural holding who had been entered in the register of agricultural holdings uninterruptedly for at least 5 years, although on the last place.

Some authors observe that a too wide definition of preemptors makes more probable that the preemption right could be exercised contrary to its statutory purpose. Such situation may emerge in practice when a preemptor exercises his priority right as a 'strawman' - not for using the land for own agricultural production, but for disposing of the same land to the benefit of a third person who does not have a statutory preemption right, usually through a combination of contracts which are per se, taken individually, not unlawful, while the whole combination of transactions runs against the basic purpose of statutory preemption right. The theory claims that such combination of transactions infringes the Act and makes the transactions concerned null and void.

\footnotetext{
73 The conditions and procedures for such a review are various. If the French 'sociétés d'aménagement foncier et d'établissement rural (SAFER)', in exercising their statutory preemption right, consider the price and other terms of sale to be 'exaggerated', they may, with the approval of the administrative authority, send a counter-offer to the notary of the seller with terms made by the SAFER. Afterwards, the seller may remove its offer or initiate a procedure before the court which reviews the price offered by the SAFER (Code rural et de la pêche maritime,

Art. L143-10). According to the German legislation, the competent authority may refuse to approve the transaction relating to agricultural land if "he consideration is roughly unproportional to the value of the land" ( $\Omega 9$ Grundstückverkehrsgesetz, GrdstVG). The European Commission also aknowledges that "State interventions to prevent excessive farmland prices may under certain circumstances be justified under EU law" (Interpretative Communication on the Acquisition of Farmland and European Union Law (2017/C 350/05), OJ C 350, 18.10.2017, 13).

${ }^{74}$ Decision repealing Chapter III of the Agricultural Land Act with one year suspension deadline 37. para.

75 Rejc 2018, 273.
} 
Sham transactions which cover other transaction that is really desired by the contractual parties are even more difficult to prove, as both contractual parties are interested in keeping secret their actual will. ${ }^{76}$

As legal transactions are based on contractual freedom, it is questionnable if partial restrictions of this freedom (like statutory preemption right) would be more effective when the legislator introduces another restriction (for instance restricted circle of potential donees of agricultural land) in order to render the circumvention more difficult. In the contract law, based on the priniciple of contractual freedom, the parties would sooner or later find another contract type in order to avoid the statutory preemption right. The problem of the Slovenian agricultral land law seems to lie in the fact that it is too much occupied with certain contract types instead of assessing the results of the transaction.

The Draft Act from spring 2019 proposed the equal treatment of preemptors regardless of their legal form (legal entity, individual entrepreneur or other individual as head of the agricultural holding), defining priority order on easily provable criteria (entry in register of agricultural holding, residence, size of the holding, obtaining certain support from the rurral development programme). However, the proposals probably gave too much accent to the size of agricultural holdings and too little to qualification of preemptors for agricultural activity.

Given the proposed priority order and especially the minimum requiremment of 5 -year registration in the register of agricultural holdings, new entrants could hardly, if at all, acquire agricultural land through sale and purchase contract, while the heads of smaller agricultural holdings, having adequate qualifications and financial means for their development plans are placed, if not neighbours, on the last place.

Finally, better regulation of agricultural preemption right and agricultural land policy would require a continuous closer monitoring, gathering and processing of statistical data relating to the exercise of statutory preemption rights on agricultural land in practice.

76 Ibid. 293. 
Franci Avsec

The preemption right on agricultural land in Slovenia: past developments and future challenges
Journal of Agricultural and

Environmental Law

$28 / 2020$

\section{Bibliography}

1. Act Amending and Supplementing Certain Laws in the Field of Agricultural Land Policy, https://e-uprava.gov.si/drzava-in-druzba/e-demokracija/predlogipredpisov/predlog-predpisa.html?id=10268 [27.04.2020]

2. Čeferin E (1973) Zakon o kmetijskih zemljiščih s komentarjem, Ljubljana.

3. Čeferin E. (1988) Prenos lastninske pravice na kmetijskih zemljiščih na podlagi prodajne, denarne in menjalne pogodbe, Pravnik: revija za pravno teorijo in prakso, 43(1/2), pp. 101-123.

4. Decision no. U-I-340-96 (12.3.1998), http://odlocitve.usrs.si/sl/odlocitev/US18854 [27.04.2020]

5. Eurostat (2012) LUCAS - Land Use and Land Cover Survey, https:/ / ec.europa.eu/ eurostat/documents/4031688/5931504/KS-03-13-587-

EN.PDF/4ee08a33-36ee-40c3-bf59-3b2f5baa28e1?version=1.0 [27.04.2020]

6. Eurostat (2019) Farm structure statistics, Statistics Explained, https://ec.europa.eu/eurostat/statistics-explained/pdfscache/1191.pdf [27.04.2020]

7. Ivan Oman (1996) Dræ̌ăni z̧bor Republike Slovenije, 53. ižredna seja, https://www.dz-

rs.si/wps/portal/Home/deloDZ/seje/evidenca?mandat=I\&type $=$ sz\&uid $=38 \mathrm{E}$ A7ED9C7452515C1257832004838CD [27.04.2020]

8. Kocjan S (1979) Kmetijska zemliišra: zakon s komentarjem, Ljubljana.

9. Prinčič J (1999) V začaranem krogu: slovensko gospodarstvo od nove ekonomske politike do velike reforme 1955-1970, Cankarjeva založba, Ljubljana.

10. Rejc Ž (2018) Pravni promet s kmetijskimi zemljišči, Podjetje in delo, 14(2), p. 273.

11. Statistika REN (2018), https://www.eprostor.gov.si/fileadmin/REN/Statistike/Statistike_REN_22.10.2018.pdf [27.04.2020]

12. Rural Development Programme of the Republic of Slovenia 2014-2020 (2015), https:/ / www.program-podezelja.si/en/rural-development-programme-20142020 [27.04.2020] 